\title{
RANCANG BANGUN MODUL PRAKTIKUM APLIKASI OP-AMP BERBASIS IC 741 DAN IC 301
}

\author{
Wahyu Rizal Nugraha ${ }^{1)}$,Tan Suryani Sollu ${ }^{2}$, Ardi Amir ${ }^{3)}$ \\ ${ }^{1)}$ Mahasiswa Teknik Elektro Universitas Tadulako, \\ ${ }^{2,3)}$ Dosen Teknik Elektro Universitas Tadulako \\ Program Studi S1 Teknik Elektro, Fakultas Teknik, Universitas Tadulako \\ E-mail :wahyu.rizal16@gmail.com
}

\begin{abstract}
The objective of this research is to design and create a practicum application of op-amp (operational amplifier) based on IC 741 and IC 301. By adding the components $R$ (Resistor) $C$ (Capacitor) IC op-amp can be applied into several series. In this practical tool there are several modules of the experiment such as multiplier, the enumerator, deduction, comparison, integrator, differentiators. This tool also equipped with a series active filter such as low pass filter, high pass filter, band pass filter and band stop filter. This practical tools requires some tool support in the form of power supply as an input voltage, a function generator to generate signals with different shapes as desired in accordance with the requirements when the practical activities and the oscilloscope as a tool of reader input waveform and the output of the circuit that exist in practical tools. Practical activities and oscilloscopes as input and output wave reader from the circuits in the practicum
\end{abstract}

Keywords: op-amp, active filter, IC 740, IC 301

\section{I .PENDAHULUAN}

Penguat operasional (operational amplifier) telah di gunakan selama bertahuntahun. Pada masa-masa awal, penguat operasional di buat dengan menggunakan rangkaian- rangkaian transistor diskrit. Akan tetapi, perkembangan yang sangat pesat dari rangkaian terintegrasi (integrated circuit) telah membawa dampak yang luas bagi terjadinya revolusi atau perubahan yang sangat cepat dalam perancangan perancangan rangkaian analog. Menurut George Clayton dan Steve Winder (Operational Amplifier:2004) istilah 'penguat operasional' (Operational Amplifier) secara umum menggambarkan tentang sebuah rangkaian penguat penting yang membentuk dasar dari rangkaian penguat audio dan video, penyaring atau tapis (Filter), buffer, penguat instrumentasi, komparator atau pembanding, osilator dan berbagai macam rangkaian analog lainnya. Operational amplifier dapat di aplikasikan menjadi rangkaian-rangkaian elektronika berbagai macam fungsi dengan cara menambahkan beberapa komponen elektronika (Mike Tooley; Rangkaian Elektronik:1995).

Berdasarkan uraian diatas, dalam penelitian ini, penulis akan membuat modul praktikum dengan lebih banyak lagi pengaplikasian dari operational amplifier antara lain rangkaian penjumlah, pengurang, pembanding, pembagi, integrator, diferensiator, low pass filter, high pass filter, band pass filter, band stop filter agar mahasiswa dapat memahami lebih banyak lagi pengaplikasian dari operational amplifier secara nyata. Oleh sebab itu maka penulis mengambil judul penelitian tugas akhir "RANCANG BANGUN MODUL PRAKTIKUM APLIKASI OP-AMP BERBASIS IC 741 DAN IC 301".

\subsection{IC 741}

IC 741 merupakan operasional amplifier yang dikemas dalam bentuk dual in-line package (DIP). Kemasan IC jenis DIP memiliki tanda bulatan atau strip pada salah satu sudutnya untuk menandai arah pin atau kaki nomor 1 dari IC tersebut. Penomoran IC dalam kemasan DIP adalah berlawanan arah jarum jam dimulai dari pin yang terletak paling dekat dengan tanda bulat atau strip pada kemasan DIP tersebut. IC 741 memiliki kemasan DIP 8 pin. seperti terlihat pada gambar 1 


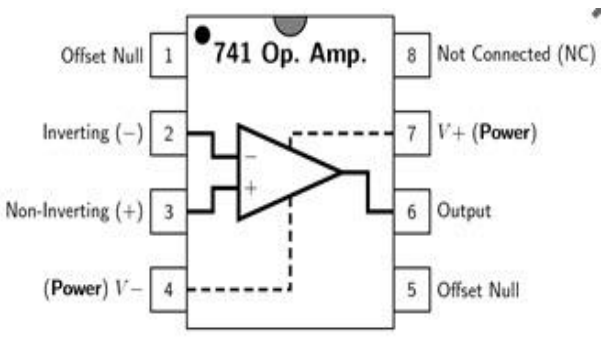

Gambar 1. IC 741

\subsection{IC 301}

IC 301 adalah penguat operasional serbaguna yang keistimewaaannya merupakan perbaikan penampilan IC $709 \mathrm{C}$ dan penguat populer lain. Teknik pemrosesan lanjut yang memungkinkan pengurangan besarnya arus input, dan perancangan kembali rangkaian pembiasan untuk memperkecil drift suhu dari arus input.

IC 301 memberikan ketelitian lebih baik dan gangguan lebih rendah dari pendahulunya pada rangkaian berimpedansi tinggi. Arus masukan yang rendah juga membuatnya secara khusus sangat cocok untuk integrator dan pewaktu berselang lama, atau rangkaian hold, cacah dan pembangkit gelombang frekuensi rendah. Selanjutnya, rangkaian pengganti dimana pasangan transistor bergandengan menyangga masukan dari IC op-amp konvensional akan memberikan tegangan offset dan drift yang lebih rendah. IC LM301 memiliki kemasan DIP 8 pin seperti terlihat pada gambar 2 .

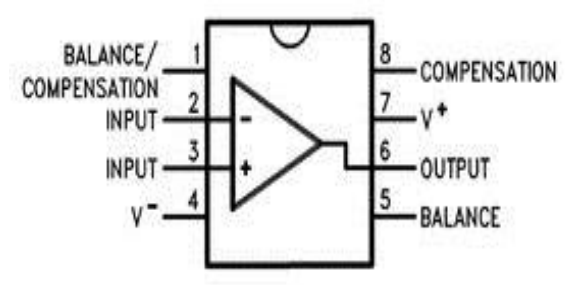

Gambar 2. IC 301

\subsection{Op-amp sebagai Penjumlah dan pengurang}

Rangkaian penjumlah adalah konfigurasi opamp sebagai penguat dengan diberikan input lebih dari satu untuk menghasilkan sinyal output yang linier sesuai dengan nilai penjumlahan sinyal input dan faktor penguat yang ada. pada umumnya rangkaian penjumlah adalah rangkaian penjumlah dasar yang disusun dengan penguat inverting dan non inverting yang diberikan input 1 line.

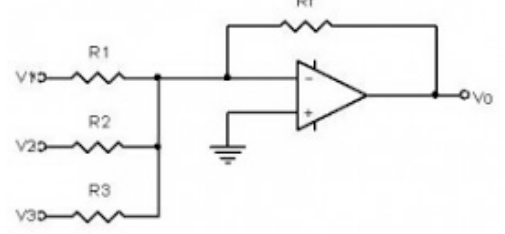

Gambar 3. Rangkaian penjumlah

Rangkaian pengurang berasal dari rangkaian inverting dengan memanfaatkan masukan noninverting, sehingga persamaannya menjadi sedikit ada perubahan.

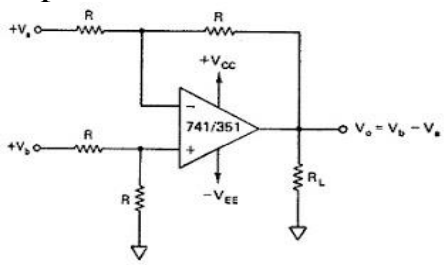

Gambar 4. Rangkaian Pengurang

\subsection{Op-amp sebagai pengali}

Rangkaian penguat inverting memiliki penguatan tegangan negatif yang besarnya ditentukan oleh perbandingan umpan balik luar (feedback) Rf dan Ri. Rangkaian pengali inverting dapat dilihat pada gambar 5
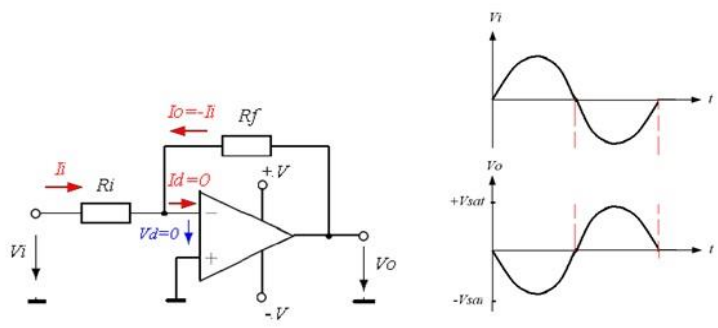

Gambar 5 Rangkaian Pengali Inverting

\subsection{Op-amp sebagai pembanding}

Komparator adalah komponen elektronik yang berfungsi membandingkan dua nilai kemudian memberikan hasilnya, mana yang lebih besar dan mana yang lebih kecil. Komparator bisa dibuat dari konfigurasi openloop op-amp. Jika kedua input pada op-amp pada kondisi open-loop, maka op-amp akan membandingkan kedua saluran input tersebut. Hasil komparasi dua tegangan pada saluran masukan akan menghasilkan tegangan saturasi positif (+Vsat) atau saturasi negatif (-Vsat). 


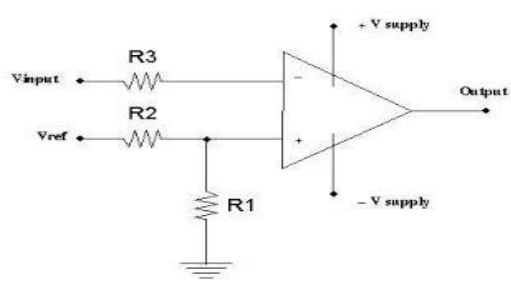

Gambar 6 Rangkaian Komparator

\subsection{Op-amp sebagai integrator dan diferensiator}

Rangkaian dasar sebuah integrator adalah rangkaian op-amp inverting, hanya saja rangkaian umpanbaliknya (feedback) bukan resistor melainkan menggunakan capasitor C. rangkaian dasar integrator dapat terlihat pada gambar 7

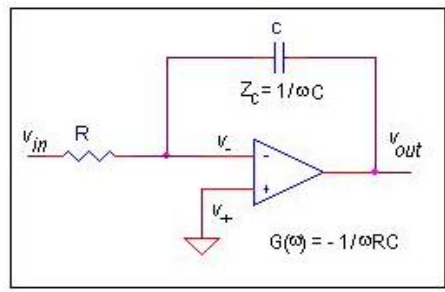

Gambar 7 Rangkaian Integrator

Jika komponen $\mathrm{C}$ pada rangkaian penguat inverting di tempatkan di depan, maka akan diperoleh rangkaian differensiator. tegangan keluaran $\mathrm{v}_{\text {out }}$ pada rangkaian ini adalah differensiasi dari tegangan input $\mathrm{v}_{\text {in }}$. Contoh praktis dari hubungan matematis ini adalah jika tegangan input berupa sinyal segitiga, maka outputnya akan mengahasilkan sinyal kotak. rangkaian dasar diferensiator terlihat pada gambar 8

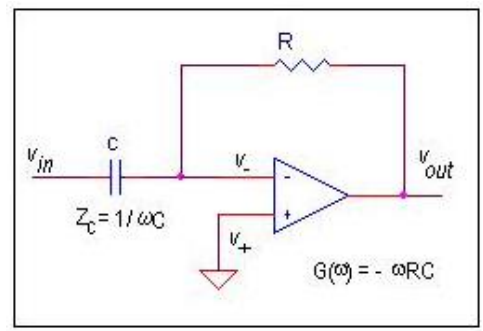

Gambar 8. Rangkaian Diferensiator

\subsection{Op-amp sebagai filter aktif}

Filter aktif sangat handal digunakan pada komunikasi dan pemerosesan sinyal, tapi juga sangat baik dan sering digunakan pada rangkaian elektronika seperti radio, televisi, telepon ,radar, satelit ruang angkasa dan peralatan biomedik. Pada filter aktif menggunakan op-amp sebagai elemen aktifnya dan tahanan, kapasitor sebagai elemen pasifnya. Biasanya dan pada umumnya IC 741 cukup baik untuk rangkaian filter aktif, namun op-amp dengan high speed seperti LM301, LM318 dan lain lainnya dapat juga digunakan pada rangkaian filter aktif untuk mendapatkan slew rate yang cepat dan penguatan serta bandwidth bidang kerja lebih baik. Umumnya filter aktif digolongkan menjadi Low Pass Filter (LPF), High Pass Filter (HPF), Band Pass Filter (BPF), Band Reject Filter (BPF)

\section{METODE PENELITIAN}

\subsection{Bahan dan Alat Penelitian}

Ada pun bahan dan alat dan digunakan dalam penelitian mengenai modul praktikum aplikasi op-amp berbasis IC 741 dan 301 adalah sebagai berikut :

\subsubsection{Bahan Penelitian}

Berikut adalah bahan-bahan yang digunakan dalam penelitian ini : IC 301, IC 741, resistor, kapasitor, Acrilyc, papan PCB

\subsubsection{Alat Penelitian}

Berikut adalah alat-alat yang digunakan Dalam penelitian ini: PC/ Laptop, Multimeter, Solder, Kabel Jumper, Shocked kabel, Power Supply, Osiloskop, Function generator

\subsection{Cara Penelitian}

Perancangan modul praktikum aplikasi opamp berbasis IC 741 dan IC 301 akan dilakukan dalam beberapa tahap mulai dari perumusan masalah sampai kemudian dilakukan percobaan, pengujian dan pengambilan data yang diperlukan.

Dari keseluruhan tahap penelitian mengenai rancang bangun modul praktikum aplikasi op-amp berbasis IC 741 dan IC 301 adalah sebagai berikut :

\subsubsection{Studi Kepustakaan}

Pada tahap studi kepustakaan dimana peneliti mencari teori-teori mengenai perancangan alat untuk pembuatan modul praktikum aplikasi op-amp dengan beberapa aplikasi yang sering di gunakan. Pada tahap ini juga dilakaukan pencarian literatur untuk mendukung skripsi ini diambil dari jurnaljurnal ilmiah dan penelitian terdahulu yang berkaitan dengan penelitian ini. 


\subsubsection{Perancangan Alat}

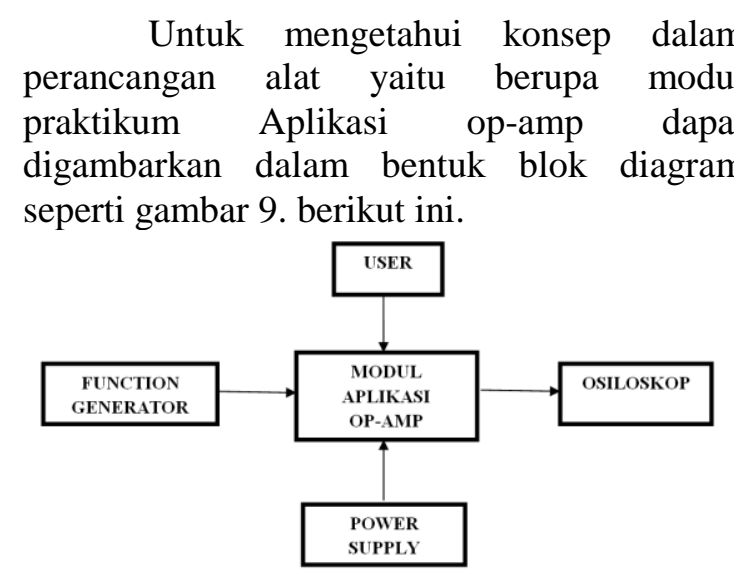

Gambar 9. Diagram blok perancangan modul Pada blok diagram, terdapat modul aplikasi dengan menggunakan dua ic op-amp yaitu IC 741 dan IC 301, IC 741 di gunakan untuk membuat apliaksi op-amp sebagai penjumlah, pengurang, pembanding, pangali, integrator dan diferensiator sedangkan IC 301 digunakan untuk membuat aplikasi op-amp sebagai low pass filter, high pass filter, band pass filter dan band stop filter

\section{HASIL DAN PEMBAHASAN}

\subsection{Hasil Penelitian}

\subsubsection{Bentuk fisik modul praktikum apliaksi} Op amp

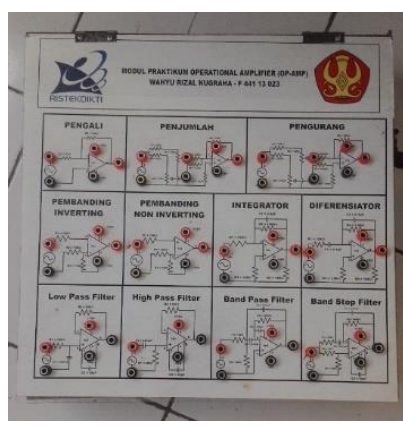

Gambar 10 Modul Praktikum op-amp

Modul ini terdiri dari beberapa rangkaian, seperti rangkaian pengali, penjumlah, pengurang, pembanding, integrator, diferensiator, low pass filter, high pass filter, band pass filter, band stop filter.

\subsubsection{Rangkaian pengali}

Rangkaian pengali tersusun dari beberapa komponen seperti IC 741, resistor $8 \mathrm{~K} \Omega$ dan resistor $10 \mathrm{~K} \Omega$ rangkaian ini mebutuhkan tegangan supply sebesar $+15 \mathrm{v}$ dan $-15 \mathrm{v}$ untuk bekerja

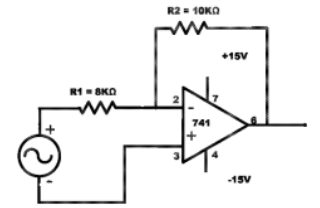

Gambar 11 Hasil rangkaian pengali

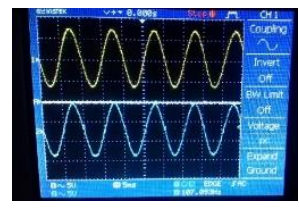

Gambar 12. Gelombang rangkaian pengali

\subsubsection{Rangkaian penjumlah}

Rangkaian penjumlah tersusun dari beberapa komponen seperti IC 741, resistor $20 \mathrm{~K} \Omega$, resistor variabel $10 \mathrm{~K} \Omega$, resistor $22 \mathrm{~K} \Omega$, resistor $2.2 \mathrm{~K} \Omega$ rangkaian ini membutuhkan tegangan supply sebesar $+15 \mathrm{v}$ dan $-15 \mathrm{v}$ untuk bekerja

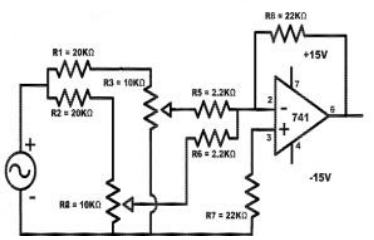

Gambar 13. Hasil Rangkaian penjumlah

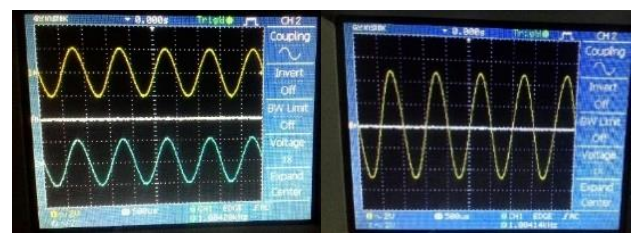

Gambar 14. Gelombang rangkaian penjumlah

\subsubsection{Rangkaian pengurang}

Rangkaian penjumlah tersusun dari beberapa komponen seperti IC 741, resistor $20 \mathrm{~K} \Omega$, resistor variabel $10 \mathrm{~K} \Omega$, resistor $22 \mathrm{~K} \Omega$, resistor $2.2 \mathrm{~K} \Omega$ rangkaian ini membutuhkan tegangan supply sebesar $+15 \mathrm{v}$ dan $-15 \mathrm{v}$ untuk bekerja

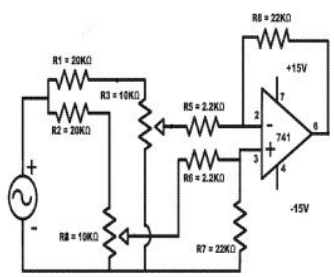

Gambar 15 Hasil rangkaian pengurang 


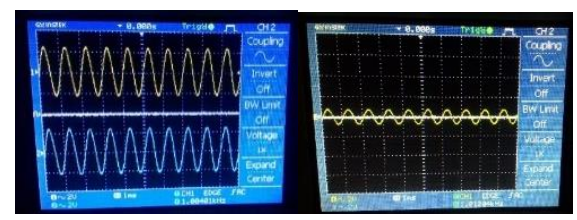

Gambar 16. Gelombang rangkaian pengurang

\subsubsection{Rangkaian pembanding}

Pada modul praktikum ini terdapat dua jenis rangkaian pembanding yaitu pembanding inverting dan pembanding noninverting Rangkaian pembanding tersusun dari beberapa komponen seperti IC 741 dan resistor $10 \mathrm{~K} \Omega$. rangkaian ini membutuhkan tegangan supply sebesar $+15 \mathrm{v}$ dan $-15 \mathrm{v}$ untuk bekerja

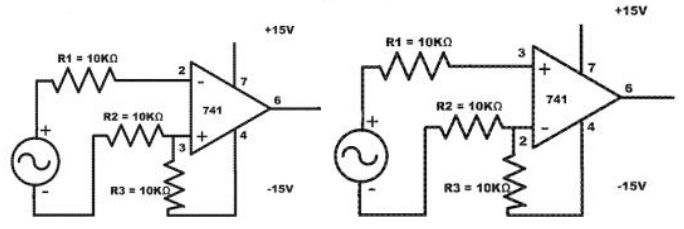

Gambar 17. Hasil Rangkaian pembanding

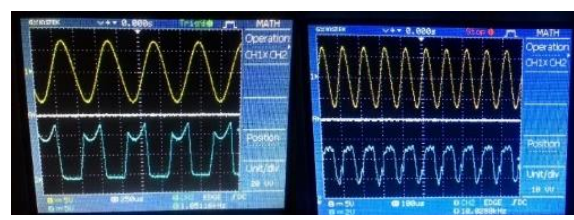

Gambar 18. Gelombang rangkaian pembanding inverting

\subsubsection{Rangkaian integrator dan diferensiator}

Rangkaian integrator tersusun dari beberapa komponen seperti IC 741, resistor $100 \mathrm{~K} \Omega$, resistor $10 \mathrm{~K} \Omega$, dan kapasitor $0.1 \mu \mathrm{F}$. Rangkaian diferensiator tersusun dari beberapa komponen seperti IC 741 , resistor $1.5 \mathrm{~K} \Omega$, resistor $10 \mathrm{~K} \Omega$, dan kapasitor $0.1 \mu \mathrm{F}$. kedua rangkaian ini membutuhkan tegangan supply sebesar $+15 v$ dan $-15 v$ untuk bekerja
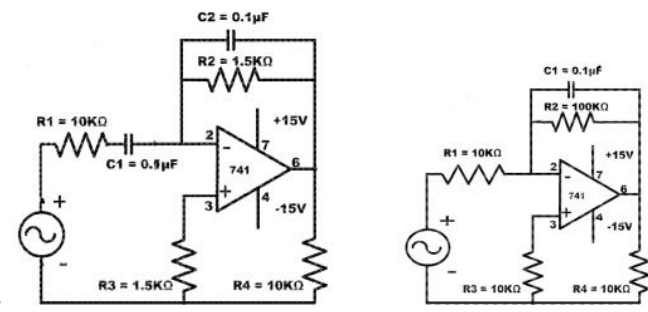

Gambar 19. Hasil Rangkaian integrator dan diferensiator

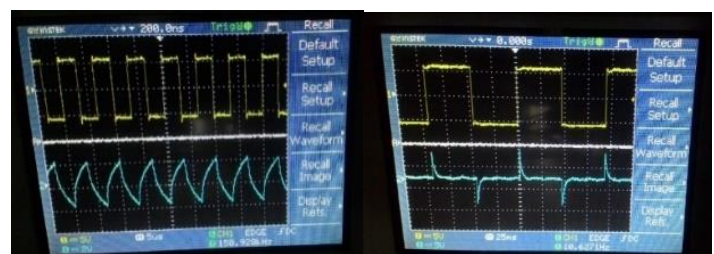

Gambar 20. Gelombang rangkaian integrator dan diferensiator

\subsubsection{Rangkaian low pass filter}

Rangkaian low pass filter tersusun dari beberapa komponen seperti IC 301, resistor $10 \mathrm{~K} \Omega$, kapasitor $0.001 \mu \mathrm{F}$, kapasitor $30 \mathrm{pF}$. rangkaian ini membutuhkan tegangan supply sebesar $+15 \mathrm{v}$ dan $-15 \mathrm{v}$ untuk bekerja

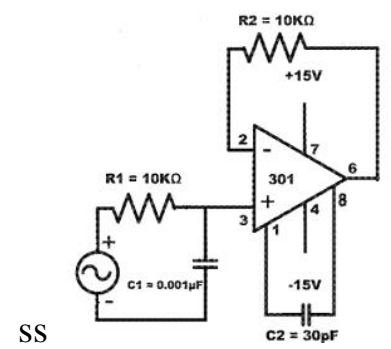

Gambar 21. Hasil Rangkaian low pass filter

Tabel 1 Output low pass filter

\begin{tabular}{|c|c|c|c|c|c|}
\hline Vin & Frekuensi & V/div & $\begin{array}{c}\text { Tinggi } \\
\text { Gelombang }\end{array}$ & Vpp & Vmax \\
\hline $15 \mathrm{~V}$ & $1 \mathrm{kHz}$ & $5 \mathrm{~V}$ & 1,9 div & $9,5 \mathrm{~V}$ & $4,75 \mathrm{~V}$ \\
\hline $15 \mathrm{~V}$ & $5 \mathrm{kHz}$ & $5 \mathrm{~V}$ & dapar & $9 \mathrm{~V}$ & $4,5 \mathrm{~V}$ \\
\hline $15 \mathrm{~V}$ & $10 \mathrm{kHz}$ & $5 \mathrm{~V}$ & 1.2 div & $6 \mathrm{~V}$ & $3 \mathrm{~V}$ \\
\hline $15 \mathrm{~V}$ & $15 \mathrm{~Hz}$ & $5 \mathrm{~V}$ & 0,9 div & $4 \mathrm{~V}$ & $2 \mathrm{~V}$ \\
\hline $15 \mathrm{~V}$ & $30 \mathrm{kHz}$ & $5 \mathrm{~V}$ & 0,5 div & $2,5 \mathrm{~V}$ & $1,25 \mathrm{~V}$ \\
\hline
\end{tabular}

Dari tabel 1 rangkaian low pass filter dapat di lihat pelemahan tegangan keluaran pada saat frekuensi semakin tinggi untuk lebih jelas dapat di lihat pada gambar 4.22

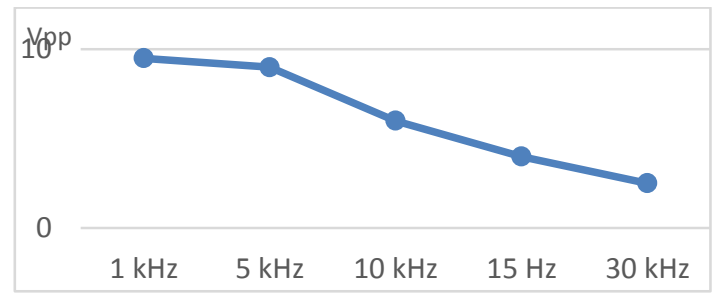

Gambar 22. Grafik low pass filter

\subsubsection{Rangkaian high pass filter}

Rangkaian high pass filter tersusun dari beberapa komponen seperti IC 301, resistor $8 \mathrm{~K} \Omega$, kapasitor $0.002 \mu \mathrm{F}$, kapasitor 
30pF. rangkaian ini membutuhkan tegangan supply sebesar $+15 \mathrm{v}$ dan $-15 \mathrm{v}$ untuk bekerja

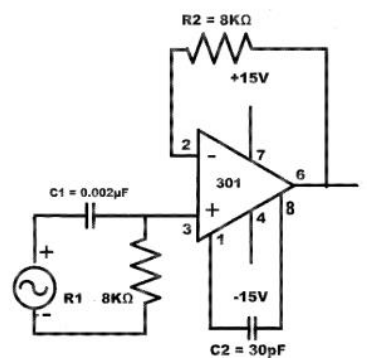

Gambar 23. Hasil Rangkaian High Pass Filter

Tabel 2 Output high pass filter

\begin{tabular}{|c|c|c|c|c|c|}
\hline Vin & Frekuensi & V/div & $\begin{array}{c}\text { Tinggi } \\
\text { Gelomban } \\
\mathbf{g}\end{array}$ & Vpp & Vmax \\
\hline $15 \mathrm{~V}$ & $5 \mathrm{KHz}$ & $1 \mathrm{~V}$ & 1 div & $1 \mathrm{~V}$ & $0,5 \mathrm{~V}$ \\
\hline $15 \mathrm{~V}$ & $1 \mathrm{KHz}$ & $1 \mathrm{~V}$ & 0,8 div & $0,8 \mathrm{~V}$ & $0,4 \mathrm{~V}$ \\
\hline $15 \mathrm{~V}$ & $700 \mathrm{~Hz}$ & $1 \mathrm{~V}$ & 0,3 div & $0,3 \mathrm{~V}$ & $0,15 \mathrm{~V}$ \\
\hline $15 \mathrm{~V}$ & $500 \mathrm{~Hz}$ & $1 \mathrm{~V}$ & 0,2 div & $0,2 \mathrm{~V}$ & $0,1 \mathrm{~V}$ \\
\hline $15 \mathrm{~V}$ & $100 \mathrm{~Hz}$ & $1 \mathrm{~V}$ & 0,1 div & $0,1 \mathrm{~V}$ & $0,05 \mathrm{~V}$ \\
\hline
\end{tabular}

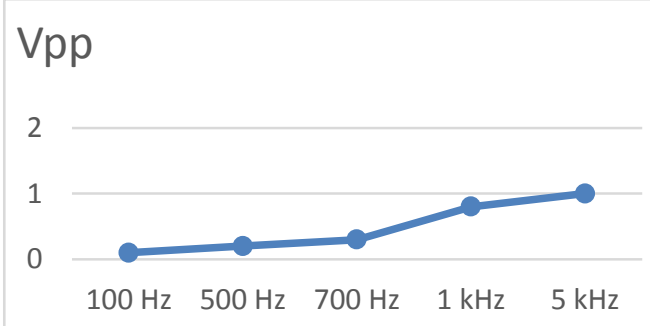

Gambar 24 Grafik High pass filter

\subsubsection{Rangkaian band pass filter}

Rangkaian band pass filter tersusun dari beberapa komponen seperti IC 301, resistor $5 \mathrm{~K} \Omega$, resistor $300 \Omega$, resistor $400 \mathrm{~K} \Omega$, kapasitor $0.01 \mu \mathrm{F}$, kapasitor $30 \mathrm{pF}$. rangkaian ini membutuhkan tegangan supply sebesar $+15 \mathrm{v}$ dan $-15 \mathrm{v}$ untuk bekerja

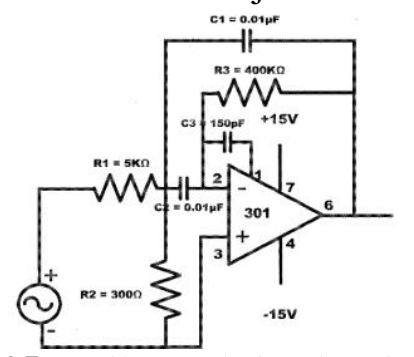

Gambar 25 Hasil Rangkaian band pass filter

Tabel 3 Output band pass filter

\begin{tabular}{|c|c|c|c|c|c|}
\hline Vin & Frekuensi & V/div & $\begin{array}{c}\text { Tinggi } \\
\text { Gelombang }\end{array}$ & Vpp & Vmax \\
\hline
\end{tabular}

\begin{tabular}{|c|c|c|c|c|c|}
\hline $15 \mathrm{~V}$ & $10 \mathrm{~Hz}$ & $5 \mathrm{~V}$ & 1,3 div & $6,5 \mathrm{~V}$ & $3,25 \mathrm{~V}$ \\
\hline $15 \mathrm{~V}$ & $50 \mathrm{~Hz}$ & $5 \mathrm{~V}$ & $1,4 \operatorname{div}$ & $7 \mathrm{~V}$ & $3,5 \mathrm{~V}$ \\
\hline $15 \mathrm{~V}$ & $1 \mathrm{KHz}$ & $5 \mathrm{~V}$ & 2,1 div & $10,5 \mathrm{~V}$ & $5,25 \mathrm{~V}$ \\
\hline $15 \mathrm{~V}$ & $100 \mathrm{KHz}$ & $5 \mathrm{~V}$ & $1,2 \operatorname{div}$ & $6 \mathrm{~V}$ & $3 \mathrm{~V}$ \\
\hline $15 \mathrm{~V}$ & $150 \mathrm{KHz}$ & $5 \mathrm{~V}$ & 1,1 div & $5,5 \mathrm{~V}$ & $2,75 \mathrm{~V}$ \\
\hline
\end{tabular}

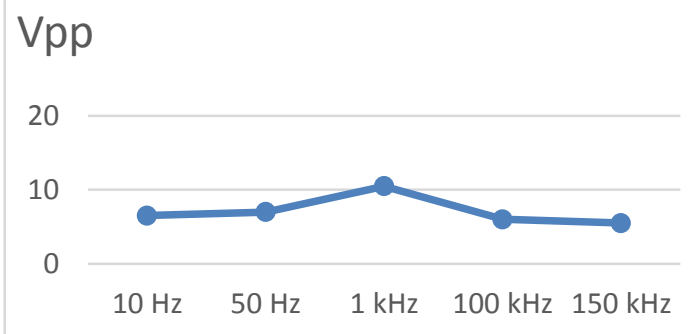

Gambar 26 Grafik Band Pass Filter

\subsubsection{Rangkaian band stop filter}

Rangkaian band stop filter tersusun dari beberapa komponen seperti IC 301, resistor $4 \mathrm{~K} \Omega$, resistor $1 \mathrm{~K} \Omega$, resistor $50 \mathrm{~K} \Omega$, resistor $400 \mathrm{~K} \Omega$ kapasitor $0.01 \mu \mathrm{F}$, kapasitor 30pF. rangkaian ini membutuhkan tegangan supply sebesar $+15 \mathrm{v}$ dan $-15 \mathrm{v}$ untuk bekerja

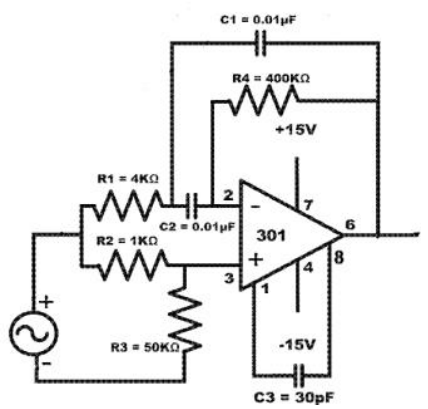

Gambar 27. Hasil Rangkaian band stop filter

Tabel 4 Output band stop filter

\begin{tabular}{|c|c|c|c|c|c|}
\hline Vin & Frekuensi & V/div & $\begin{array}{c}\text { Tinggi } \\
\text { Gelombang }\end{array}$ & Vpp & Vma \\
\hline $15 \mathrm{~V}$ & $50 \mathrm{~Hz}$ & $5 \mathrm{~V}$ & $2,2 \operatorname{div}$ & $11 \mathrm{~V}$ & 5,5 \\
\hline $15 \mathrm{~V}$ & $150 \mathrm{~Hz}$ & $5 \mathrm{~V}$ & $2,1 \mathrm{div}$ & $10,5 \mathrm{~V}$ & 5,25 \\
\hline $15 \mathrm{~V}$ & $400 \mathrm{~Hz}$ & $5 \mathrm{~V}$ & $0,2 \operatorname{div}$ & $1 \mathrm{~V}$ & 0,5 \\
\hline $15 \mathrm{~V}$ & $1 \mathrm{KHz}$ & $5 \mathrm{~V}$ & $2.2 \mathrm{div}$ & $11 \mathrm{~V}$ & 5,5 \\
\hline $15 \mathrm{~V}$ & $10 \mathrm{KHz}$ & $5 \mathrm{~V}$ & $2.3 \mathrm{div}$ & $11,5 \mathrm{~V}$ & 5,75 \\
\hline \multicolumn{6}{|c|}{ Vpp } \\
\hline \multicolumn{6}{|c|}{20} \\
\hline \multicolumn{6}{|l|}{10} \\
\hline & $50 \mathrm{~Hz}$ & $150 \mathrm{~Hz}$ & $400 \mathrm{~Hz}$ & 10 & $\mathrm{~Hz}$ \\
\hline
\end{tabular}

Gambar 28 Grafik Band Stop Filter 


\subsection{Pembahasan}

\subsubsection{Rangkaian pengali}

Op-amp sebagai pengali tegangan memiliki tegangan keluaran safasa dengan tegangan masukannya, namun bila masukan di balik pada kaki inverting maka keluarannya berbeda fasa dengan tegangan masukannya. besarnya tegangan keluaran dapat di tentukan dengan pengaturan resistansi resistansi yang di pakai.

\subsubsection{Rangkaian penjumlah}

Op-amp sebagai penjumlah memiliki tegangan keluaran safasa dengan tegangan masukannya, besarnya tegangan keluaran dapat di tentukan dengan pengaturan antara dua tegangan masukannya dengan cara memutar resistor variabel untuk mengatur besar hambatannya, pada rangkaian ini tegangan keluaran merupakan hasil penjumlahan antara tegangan masukan.

\subsubsection{Rangkaian pengurang}

Op-amp sebagai pengurang memiliki tegangan keluaran safasa dengan tegangan masukannya, besarnya tegangan keluaran dapat di tentukan dengan pengaturan antara dua tegangan masukannya dengan cara memutar resistor variabel untuk mengatur besar hambatannya, pada rangkaian ini tegangan keluaran merupakan hasil pengurangan antara tegangan masukan. Berikut hasil dari percobaan rangkaian pengurang

\subsubsection{Rangkaian pembanding}

Pada rangkaian pembanding, tegangan keluaran pada rangkaian ini merupakan hasil perbandingan antara dua masukan pada rangkaian tersebut, terdapat perbedaan antara pembanding inverting dan pembanding non inverting dimana pembanding inverting memiliki tegangan keluaran yang berbeda fasa dengan tegangan masukan sebaliknya tegangan keluaran pembanding non inverting memiliki fasa yang sama dengan sinyal masukan.

\subsubsection{Rangkaian integrator dan diferensiator}

Pada rangkaian integrator tegangan output merupakan fungsi integral dari tegangan input sedangkan tegangan output dari rangkaian diferensiator merupakan fungsi diferensial dari tegangan input.

\subsubsection{Rangkaian low pass filter}

Pada rangkaian low pass filter, filter ini melewatkan frekuensi di bawah frekuensi cutoff, dalam percobaan ini frekuensi cutoff ada pada frekuensi $15,9 \mathrm{kHz}$. Berikut perbandingan antara sinyal keluaran $(\mathrm{CH} 2)$ pada frekuensi $5 \mathrm{kHz}$, dan $15 \mathrm{kHz}$ dimana menunjukkan ada pelemahan sinyal keluaran pada frekuensi $15,9 \mathrm{kHz}$

\subsubsection{Rangkaian high pass filter}

Pada rangkaian high pass filter, filter ini melewatkan frekuensi di atas frekuensi cutoff, dalam percobaan ini frekuensi cutoff ada pada frekuensi $700 \mathrm{~Hz}$. Berikut perbandingan antara sinyal keluaran $(\mathrm{CH} 2)$ pada frekuensi $1 \mathrm{kHz}$, dan $700 \mathrm{~Hz}$ dimana menunjukkan ada pelemahan sinyal keluaran pada frekuensi 700 $\mathrm{Hz}$

\subsubsection{Rangkaian band pass filter}

Pada rangkaian band pass filter, filter ini tidak melewatkan seluruh sinyal masukan kecuali sinyal tertentu, dalam percobaan ini sinyal yang di lewatkan ada pada frekuensi $1 \mathrm{kHz}$. Berikut perbandingan antara sinyal keluaran (CH2) pada frekuensi $50 \mathrm{~Hz}, 1 \mathrm{kHz}$ dan 100 $\mathrm{kHz}$ dimana menunjukkan ada penguatan sinyal keluaran pada frekuensi $1 \mathrm{kHz}$

\subsubsection{Rangkaian band stop filter}

Pada rangkaian band stop filter, filter ini melewatkan seluruh sinyal masukan kecuali sinyal tertentu, dalam percobaan ini sinyal yang tidak di lewatkan ada pada frekuensi 400 $\mathrm{Hz}$. Berikut perbandingan antara sinyal keluaran $(\mathrm{CH} 2)$ pada frekuensi $150 \mathrm{~Hz}, 400$ $\mathrm{Hz}$ dan $1 \mathrm{kHz}$ dimana menunjukkan ada pelemahan sinyal keluaran pada frekuensi 400 $\mathrm{Hz}$

\section{PENUTUP}

\subsection{Kesimpulan}

Berdasarkan hasil perancangan dan pembuatan Modul Praktikum op-amp berbasis IC 741 dan 301 serta hasil dari pengujian dengan melakukan beberapa percobaan osiloskop, maka dapat ditarik kesimpulan bahwa :

1. IC op-amp seperti IC 741 dan IC 301 dapat di aplikasikan menjadi rangkaian rangkain yang mempunyai banyak fungsi antara lain sebagai pengali, penjumlah, pengurang, pembanding hanya dengan menambahkan komponen R (resistor).

2. Pada rangkaian integrator, tegangan output merupakan fungsi integral dari tegangan input sedangkan tegangan output dari 
rangkaian diferensiator merupakan fungsi diferensial dari tegangan input

3. IC op-amp 301 dapat digunakan sebagai filter aktif antara lain low pass filter, high pass filter, band pass filter dan band stop filter dengan baik

4. Parameter - parameter seperti kualitas komponen yang digunakan, penyolderan, perangkat - perangkat yang digunakan dalam pengujian sumber sinyal, kabel kabel, atau alat ukur serta variabel noise sangat menentukan kualitas gelombang hasil modulasi

\subsection{Saran}

1. Untuk pengembangan modul praktikum aplikasi op-amp dapat dilakukan dengan menambahkan aplikasi lain yang belum terdapat pada modul tersebut seperti rangkaian osilator dan schmitt trigger.

2. Dalam penggunaan IC op-amp dapat menggunakan IC yang lebih beragam lagi agar dapat mengetahui karakteristik lebih banyak IC op-amp yang ada.

3. Dalam pegambilan data hasil pengujian modul praktikum aplikasi op-amp dapat menggunakan alat pendukung seperti osiloskop dan function generator yang dalam keadaan baik untuk menghindari noise pada gelombang sinyal.

\section{DAFTAR PUSTAKA}

Agus, P. 2012. Operasinal Amplifier, https://elektronikadasar.web.id/operational-amplifier/ diakses: 10 oktober 2017.

Arief F, 2017. Rancang bangun modul praktikum opasional amplifier, Skripsi, ITS, Surabaya.

Mike Tooley. 2003. Rangkaian elektronik prinsip dan aplikasi, Erlangga, Jakarta.

Robert F. Coughlin \& Frederick F. Driscoll. 1992. Penguat operasional dan rangkaian terpadu linear, Erlangga, Jakarta. 